\title{
Innovative Teaching: A Qualitative Review of Flipped Classrooms
}

\author{
Kevin Fuchs \\ Prince of Songkla University, Phuket, Thailand \\ https://orcid.org/0000-0003-3253-5133
}

\begin{abstract}
The extent and importance of web-based learning in higher education have increased tremendously in the last decade, triggered by new educational technologies and pedagogical approaches. Higher education lecturing has traditionally followed a teacher-centered approach, with lecturers giving classes in the classroom and students performing out-of-class activities. Under this traditional approach, the main actor in the teaching-learning process is the lecturer, while students play a passive role. The flipped classroom emphasizes the role of the student in the center of the learning environment and facilities an active learning pedagogy. This paper reviews the most recent case studies related to the flipped classroom approach in order to provide educators guidelines on the best practices, traits, and merits of the flipped classroom. A total of 22 case studies were included in this qualitative review of the flipped classroom. The methodological inquiry followed the PRISMA flow diagram that identified an initial pool of 3,764 articles. Upon identification of relevant case studies $(n=22)$, a fivepoint Likert-type sentiment rating was assigned as the basis to structure the discussion. The rating was based on the students' perceptions of the flipped classrooms as investigated in the articles. The assessment confirms that the majority of students have a positive perception of this learning pedagogy. However, there are concerns about increased workload for students, ambiguity in expected learning outcomes, and an initial barrier to actively contribute; these are the primary implications of this review.
\end{abstract}

Keywords: flipped classroom; inverted learning; active learning; constructivism; TEFC

\section{Introduction}

Both the importance and extent of web-based or online learning in higher education have increased vastly in the last decade. As a result, this trend has been further accelerated by new educational technologies and pedagogical approaches while educators continue to debate the best practices and approaches for their classrooms. The variety of courses have continued to increase in scale and scope and the sudden COVID-19 crisis in early 2020 has 
further fast-tracked universities' implementation of online teaching (Tang et al., 2020). Flexibility with regard to the workload and allowing the students to make decisions about when and what they learn are two of the primary advantages of technology-enhanced learning (TeL). Besides, research has indicated that online learning is pedagogically promising because it encourages deeper learning via its self-paced and student-centered approach (Tang et al., 2020). The flipped classroom is a versatile and well-researched pedagogical approach that facilitates active learning with the power of peer learning (Crews \& Butterfield, 2014; Thai, De Wever \& Valcke, 2017). It is the objective of this paper to share a review of the existing literature and provide comprehensive insights by outlining the most important traits of the flipped classroom, merits with regard to student development, and shortcoming of this pedagogical approach. It is not within the scope of this review to examine the perspective of the educator or the institution, but to provide a holistic overview from the perspective of students. The important findings of the most recent case studies in 2019 and 2020 contribute to the body of knowledge and close an identified research gap. Through the findings of this review paper, educators will be able to obtain practical guidance which will help them implement the most effective methods for their flipped classroom courses. The next chapter will provide insights into the conceptual design of a flipped classroom.

\subsection{Conceptual design of a flipped classroom}

The design and implementation of flipped classrooms largely depends on the educators, yet there is no consensus with regard to a universal design of a flipped classroom (Thai, De Wever \& Valcke, 2017). However, a recurring claim regarding the design of a flipped classroom is that there are three particular consecutive phases (Figure 1). Crews and Butterfield (2014) noted that the preclass, during-class, and post-class stages are essential elements when implementing a flipped classroom. There is an agreement in the literature that the first phase of a flipped classroom takes place as a prerequisite for students to acquire fundamental knowledge (Thai, De Wever and Valcke, 2017). During this phase, the students are expected to work individually in anticipation of the second phase. This stage is typically administered through a Learning Management System (LMS) with online tutorials, lecture notes, video clips prepared by the teacher, or other course material (Crews \& Butterfield, 2014). The second phase is considered the most influential phase in the flipped classroom design and determines the impact on the students' learning within the paradigm of active learning (Thai, De Wever \& Valcke, 2017). This studentcentered approach places emphasis on discussion amongst peers, wherein the teacher acts as a facilitator of the discussion (Fuchs, 2021). 


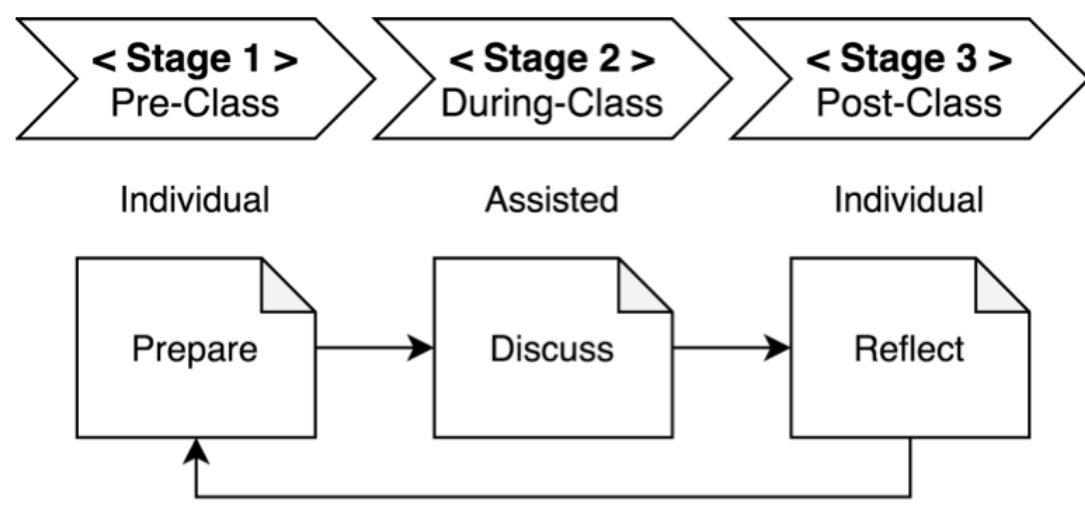

Figure 1: A simplified design of a flipped classroom (adapted from Fuchs, 2021)

The post-class phase is designed to allow the students to reflect on the content of the pre-class phase in combination with the peer-discussion in the during-class phase (Lo, Lie \& Hew; 2018). This last phase is oftentimes accompanied by a personal learning assignment to reflect on the newly constructed knowledge (Crews \& Butterfield, 2014; Thai, De Wever \& Valcke, 2017).

\section{Methods}

A comprehensive review of the literature was conducted using the PRISMA flow diagram in order to cross-examine case studies and identify which characteristics of flipped classrooms were most commonly researched, as well as what additional calls for future research had been stated. Moreover, upon identifying the 22 case studies that were reviewed, a sentiment score was assigned to each paper.

\subsection{The PRISMA flow diagram}

The Preferred Reporting Items for Systematic Reviews flow diagram, or PRISMA, was developed by a delegation of 29 review authors, medical editors, consumers, clinicians, and methodologists (Liberati et al., 2009). In 2005, the focus group attended a three-day meeting and participated in extensive postmeeting digital correspondence. A consensus was reached concerning the optimal process. Henceforth, a 27-item checklist and a four-phase flow diagram was developed (Liberati et al., 2009; Stovold et al., 2014). Liberati et al. (2009) further noted, "PRISMA focuses on ways in which authors can ensure the transparent and complete reporting of systematic reviews and meta-analyses" (Liberati et al., 2009, p. 120).

\subsection{The search process}

A search in the abstract and citation database Scopus was conducted and yielded 3,752 records in January 2021 (Figure 2). The inquiry was guided by the keywords "flipped classroom" and "flipped learning". A large volume of literature was retrieved and further criteria were applied to refine the results. The following five limits were set:

- $\quad$ articles dated in 2019 and 2020

- a focus on social science and business as the subject area 
- publication stage: final

- publication language limited to English

- source type was set to journal and conference proceeding

This exact search syntax was used:

"TITLE-ABS-KEY ("flipped classroom") AND ( LIMIT-TO (
PUBSTAGE,"final" ) ) AND ( LIMIT-TO ( LANGUAGE,"English")
) AND ( LIMIT-TO ( SRCTYPE,"j" ) OR LIMIT-TO ( SRCTYPE,"p"
) AND ( LIMIT-TO ( PUBYEAR,2020) OR LIMIT-TO (
PUBYEAR,2019) )"

An additional 12 publications that were not Scopus-indexed, but the content of which were familiar to the author, were included in this stage of the process based on their merits. The identification stage was concluded with a total of 1,187 items that qualified for further screening.

The first stage of the screening process included reviewing each title of the 1,187 records. In this stage, a total of 752 records were excluded. In the second stage of the screening process, another 317 records were excluded based on reviewing their abstracts. A total of 118 articles were deemed eligible for full-text analysis. In this final step, 96 articles were excluded wherein 79 were out of scope, 13 had insufficient information about the methodology, and 4 were not adaptable to the scope of this review. Eventually, 22 relevant case studies were selected for indepth analysis.

\subsection{Appointing a sentiment score}

A Likert-type rating system was utilized to assign a descriptive score to each article that was included in the review. The following descriptive scores were based on the Likert-type scale. The highest descriptive score corresponded to the label "Positive", the second-highest "Slightly Positive", followed by "Neutral, "Slightly Negative", and finally "Negative". Every article included in this paper $(n=22)$ was assigned a descriptive score by the reviewer (the author of this report). The assessment for each score was based on the conclusion of the article in regard to the participants' perceptions of the flipped classroom. The purpose of the sentiment score was to classify the articles into different categories and to generate a variable for further analysis. After each article was assigned a descriptive score, the author asked a colleague for an informal peer-review to validate the results. Any opposing views were discussed until a consensus was reached. 


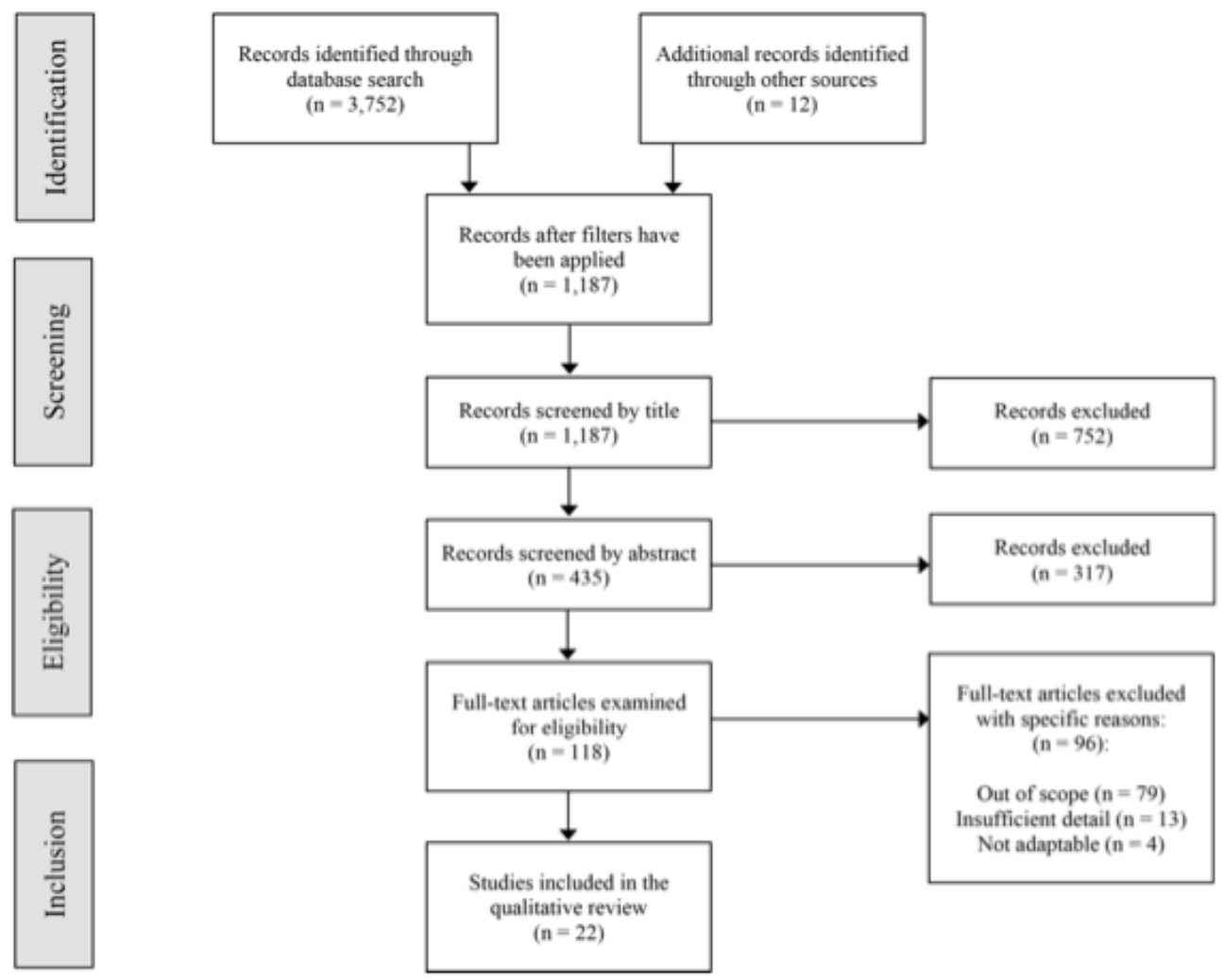

Figure 2: PRISMA flow diagram for a review of the literature

\section{Flipping Classes: Where does all the hype come from?}

The 22 articles that were included (Table 1) as the result of the PRISMA procedure were reports of quantitative, qualitative, or mixed methods inquiries. Within the criteria that were used to retrieve the literature, the majority of articles had conducted quantitative research $(n=10)$, followed by mixed methods $(n=8)$ and with only four qualitative studies $(n=4)$ reviewed. The most common means of analysis for quantitative research was descriptive analysis as opposed to thematic analysis. The sample size for the quantitative studies ranged from the smallest sample of 52 participants [No. 10] to 495 participants [18]. The mixed-methods approach utilized sample sizes ranging from 42 [No. 05] up to the largest sample of 152 participants [No. 02]. Naturally, the sample size for purely qualitative research was smaller and ranged from 13 participants for the smallest study included [No. 08] to 25 participants in the largest qualitative study [No. 15]. To collect versatile and comprehensive information on previous studies about flipped classrooms, there was no limitation placed on the geographical location of the sampling. This allowed for the generation of a broad perspective and analysis of results from different learning environments and learning cultures. While no specific limitations were applied to the origin of the study, it can be noted that four (4) studies originated from Spain, three (3) from Australia, and the remainder were single studies, each representing one of 15 countries (Table 1). 
Table 1: Summary of articles included in this review

\begin{tabular}{|l|l|l|l|l|}
\hline No. & Author/s (Year) & Type of Inquiry & Sample & Origin Country \\
\hline$[01]$ & $\begin{array}{l}\text { Murillo-Zamorano et al. } \\
(2019)\end{array}$ & Quantitative Method & $\mathrm{N}=160$ & Spain \\
\hline$[02]$ & Castedo et al. (2019) & Mixed Methods & $\mathrm{N}=152$ & Spain \\
\hline$[03]$ & Kay et al. (2019) & Quantitative Method & $\mathrm{N}=103$ & Canada \\
\hline$[04]$ & Lopes et al. (2019) & Quantitative Method & $\mathrm{N}=152$ & Portugal \\
\hline$[05]$ & Goedhart et al.(2019) & Mixed Methods & $\mathrm{N}=42$ & Netherlands \\
\hline$[06]$ & Cai et al. (2019) & Quantitative Method & $\mathrm{N}=111$ & China \\
\hline$[07]$ & Tomas et al. (2019) & Mixed Methods & $\mathrm{N}=171$ & Australia \\
\hline$[08]$ & Ha et al. (2019) & Qualitative Method & $\mathrm{N}=13$ & Hong Kong \\
\hline$[09]$ & Cilliers \& Pylman (2020) & Quantitative Method & $\mathrm{N}=82$ & South Africa \\
\hline$[10]$ & Stöhr et al. (2020) & Quantitative Method & $\mathrm{N}=52$ & Sweden \\
\hline$[11]$ & $\begin{array}{l}\text { Martínez-Jiménez et al. } \\
(2020)\end{array}$ & Quantitative Method & $\mathrm{N}=58$ & Spain \\
\hline$[12]$ & Abdekhoda et al. (2020) & Quantitative Method & $\mathrm{N}=110$ & Iran \\
\hline$[13]$ & $\begin{array}{l}\text { Colomo-Magaña et al. } \\
\text { (2020) }\end{array}$ & Quantitative Method & $\mathrm{N}=123$ & Spain \\
\hline$[14]$ & Alamri (2019) & Mixed Methods & $\mathrm{N}=52$ & Saudi Arabia \\
\hline$[15]$ & Wilson (2020) & Qualitative Method & $\mathrm{N}=25$ & Australia \\
\hline$[16]$ & Alebrahim \& Ku (2020) & Qualitative Method & $\mathrm{N}=14$ & United States \\
\hline$[17]$ & $\begin{array}{l}\text { Aprianto \& Purwati } \\
\text { (2020) }\end{array}$ & Qualitative Method & $\mathrm{N}=15$ & Indonesia \\
\hline$[18]$ & Aljaraideh (2019) & Quantitative Method & $\mathrm{N}=495$ & Jordan \\
\hline$[19]$ & Almisad (2019) & Mixed Methods & $\mathrm{N}=27$ & Kuwait \\
\hline$[20]$ & Bhat et al. (2020) & Mixed Methods & $\mathrm{N}=32$ & India \\
\hline$[21]$ & Awidi \& Paynter (2019) & Mixed Methods & $\mathrm{N}=117$ & Australia \\
\hline$[22]$ & Bicen \& Beheshti (2019) & Mixed Methods & $\mathrm{N}=130$ & Cyprus \\
\hline
\end{tabular}

\subsection{The polarizing effect of flipped classrooms}

Due to emerging educational technology and pedagogical methods, the extent and value of online learning in higher education has increased tremendously in the last decade. Teaching in higher education has conventionally followed a teacher-centered method, with lecturers providing classroom courses and students conducting out-of-class tasks. In this conventional method, students play a passive role and the instructor is the key player in the teaching-learning process (Murillo-Zamorano et al., 2019). A new viewpoint is provided by the flipped classroom, in which education is student-centered and the lecturer has shifted into a passive role.

"Flipping the classroom means that the traditional classroom becomes inverted." (Murillo-Zamorano et al., 2019)

Students are expected to regularly collect information by reading, watching recorded lectures, or listening to podcasts outside of class time. This relates to the two bottom levels of Bloom's Taxonomy, which allow students to remember and process the class information given. The student is then required to apply the knowledge they have acquired to problem-solving activities in groups through peer instruction during classroom time. These tasks may include case study research, analyzing different scenarios, and developing new problem 
solutions that conform to Bloom's Taxonomy's higher-order level. When students have a more extensive and comprehensive understanding of the content, this makes for a better learning experience (Cilliers \& Pylman, 2020).

Lopes et al. (2019) indicated that students are required to dedicate themselves to being self-directed in their learning. This is particularly pertinent in the classroom's e-learning aspect, which implies a cultural shift from an academic point of view that can be pursued persistently, mainly in the context of higher education (Lopes et al., 2019). The flipped classroom has been conceived as a student-centered pedagogical method aiming to enhance the performance of students. The literature recognized the flipped classroom's potential over conventional methods for teaching and learning (Murillo-Zamorano et al., 2019). Besides, to achieve comparable pre-knowledge and comprehension levels, the self-regulated pre-class learning combination through prescribed reading and video materials was considered to have merit, particularly in a diverse student population alongside in-class activities integrating collaborative learning activities which promote deeper learning (Goedhart et al., 2019; Lopes et al., 2019).

Following the flipped approach to the classroom and to achieve a successful learning outcome, the results of Murillo-Zamorano et al. (2019) trigger the following essentials to be taken into account: firstly, there should be two-way input (instructor to students and vice versa) as an efficient link between in-class and out-of-class activities. Secondly, technology is used to move the lecture outside (Murillo-Zamorano et al., 2019). Even though the overall experience was pleasant, it was disappointing to see that some of the students claimed that the flipped classroom did not contribute to their learning outcomes (Goedhart et al., 2019). To effectively promote student participation and constructive learning, teachers are often expected to incorporate several in-class pedagogical modifications (Cai et al., 2019).

Moreover, the author performed an informal assessment of the 22 articles that were included in the review and assigned an individual sentiment rating to each article. A peer validated the rating by consensus with the reviewer and it ranged through positive, slightly positive, neutral, slightly negative, and finally negative on a five-point Likert-type scale. This approach was adapted from Qiu et al. (2018), who used a similar technique to categorize articles based on the sentiment expressed in the conclusion. In this context, the author assigned the sentiment rating based on how the flipped classroom pedagogy was perceived by the university students in the 22 articles. Furthermore, the author modified the model from Qui et al. (2018) and sliced the results based on their type of inquiry (Table 2). This aimed to identify whether there was a pattern between the students' perceptions and the strategy of how the data were collected. 
Table 2: Cross-examination by sentiment and method

\begin{tabular}{|l|l|l|}
\hline Sentiment & Type of Inquiry & Case Study No. \\
\hline \multirow{4}{*}{ Positive } & Quantitative Method & {$[01],[04],[09],[11],[12],[13],[18]$} \\
\cline { 2 - 3 } & Mixed Methods & {$[14],[19],[20],[22]$} \\
\cline { 2 - 3 } & Qualitative Method & {$[17]$} \\
\hline Slightly Positive & Mixed Methods & {$[02],[05],[21]$} \\
\hline \multirow{3}{*}{ Neutral } & Quantitative Method & {$[03],[06]$} \\
\cline { 2 - 3 } & Qualitative Method & {$[16]$} \\
\cline { 2 - 3 } & Mixed Methods & {$[07]$} \\
\hline Slightly Negative & Qualitative Method & {$[08]$} \\
\hline Negative & Quantitative Method & {$[10],[15]$} \\
\hline
\end{tabular}

It can be noted that a simple majority of the studies were assigned a positive rating. Out of the total 22 articles, 12 received a positive sentiment rating and, at the other end of the spectrum, two (2) received a rating indicating a negative perception towards the flipped classroom by the students. The remaining eight (8) case studies fall in between, wherein (3) of them were rated slightly positive, four (4) neutral, and one (1) slightly negative. The author did not identify any pattern or correlation between the strategy of inquiry and the sentiment rating of the study. While some of the flipped classroom case studies are associated with a negative perception by the participating students, it can be stated that a large majority $(68 \%)$ had, at the minimum, a positive attitude towards this new active learning approach. The sentiment rating helped to determine the general tone amongst the selected case studies (Al-Natour \& Turetken, 2020). In the following, a more in-depth examination into both the challenges and positive aspects of the flipped classroom pedagogy will be provided.

\subsection{Flipped Classrooms: A remedy to achieve inclusive education?}

As a consequence of the flipped classroom approach, Wilson (2020) identified a significant problem in the students' workload. Also, it is recommended that a lower workload could be tested to determine whether the same instructional result could still be obtained. The paper highlights major concerns related to flipped learning pedagogy due to the increased workload (Wilson, 2020). Furthermore, Stöhr et al. (2020) were unable to confirm the flipped classroom's reported positive effect in higher education in a quantitative assessment that contrasted the flipped classroom with conventional lecture-based learning. Ha et al. (2019) discussed beneficial outcomes of the flipped approach to the classroom; in their case, the researchers indicated that students had adapted to a "spoon-fed" system and, thus, initially failed to respond to the flipped model of the classroom (Ha et al., 2019). A related observation was reported by Castedo et al. (2019), in which students initially failed to respond to the latest method. Kay et al. (2019) as well as Alebrahim and $\mathrm{Ku}$ (2020) defined positive and negative perceptions; both studies concluded that there is a need for clarification, flexibility, timely instruction, and feedback in the implementation of a flipped classroom. Besides, it was observed that the transfer of materials from the conventional face-to-face model to the computer-mediated format requires specialized expertise, time, and dedication (Cai et al., 2019). Moreover, the usage of efficient technology must be reviewed beforehand because this helps facilitate outside-class engagement amongst students (Aprianto \& Purwati, 2020). These 
suggestions shared by Cai et al. (2019) and Aprianto and Purwati (2020) demonstrate that there is still uncertainty among students when it comes to technology-enhanced learning (TEL).

Table 3: Empirical findings of the selected case studies

\begin{tabular}{|c|c|}
\hline No. & Empirical findings \\
\hline [01] & $\begin{array}{l}\text { FC has positive effects on students' knowledge, skills, and } \\
\text { engagement. }\end{array}$ \\
\hline [02] & $\begin{array}{l}\text { Initial reluctance towards the FC methodology, but finally a higher } \\
\text { attendance than traditional learning }\end{array}$ \\
\hline [03] & $\begin{array}{l}\text { Identified a need for clarity, flexibility, timely guidance and feedback, } \\
\text { and cognitive engagement }\end{array}$ \\
\hline [04] & $\begin{array}{l}\text { FC requires a high level of teacher work and creativity in developing } \\
\text { content and then properly organizing it }\end{array}$ \\
\hline [05] & $\begin{array}{l}\text { The combination of self-regulated pre-class learning in combination } \\
\text { with in-class activities facilitates deeper learning }\end{array}$ \\
\hline [06] & $\begin{array}{l}\text { The migration of materials from traditional face-to-face format to } \\
\text { computer-mediated format is a process that requires specific skills, as } \\
\text { well as a significant amount of time and effort }\end{array}$ \\
\hline [07] & $\begin{array}{l}\text { Respondents' opinions regarding whether a flipped classroom } \\
\text { motivated them to learn, or was more engaging than traditional } \\
\text { instruction, were divided }\end{array}$ \\
\hline [08] & $\begin{array}{l}\text { Students that were used to a "spoon-fed" approach initially struggled } \\
\text { to adapt to the flipped classroom model }\end{array}$ \\
\hline [09] & $\begin{array}{l}\text { The activities done in the classroom provided real-life experience that } \\
\text { could be used for problem-solving when they enter the workplace }\end{array}$ \\
\hline [10] & $\begin{array}{l}\text { Results do not confirm the documented positive effect of the flipped } \\
\text { classroom in STEM education }\end{array}$ \\
\hline [11] & $\begin{array}{l}\text { The academic results have been better in which the flipped learning } \\
\text { methodology was implemented }\end{array}$ \\
\hline [12] & $\begin{array}{l}\text { An approach that encourages active learning and improves student } \\
\text { performance; meanwhile decreasing the failure rate in education }\end{array}$ \\
\hline [13] & $\begin{array}{l}\text { Sample responded positively to the initiative to implement the flipped } \\
\text { classroom and appreciated its potential to promote learning }\end{array}$ \\
\hline [14] & $\begin{array}{l}\text { Results demonstrated improved student academic achievement and } \\
\text { satisfaction, compared with the traditional lecture-based approach }\end{array}$ \\
\hline [15] & $\begin{array}{l}\text { This study highlights important problems associated with Flipped } \\
\text { Learning pedagogy and suggests future research in divergent } \\
\text { pedagogies attend to the critical issues of student workload, and to } \\
\text { consider if the same educational outcome could be achieved equally as } \\
\text { well by a lower workload pedagogy. }\end{array}$ \\
\hline [16] & $\begin{array}{l}\text { Positive and negative opinions depending on how they implemented } \\
\text { the flipped classroom including the engagement of students and the } \\
\text { environment }\end{array}$ \\
\hline [17] & $\begin{array}{l}\text { The use of efficient technology must be reviewed prior to use because } \\
\text { it helps facilitate outside-class engagement amongst students }\end{array}$ \\
\hline [18] & $\begin{array}{l}\text { Generally a high satisfaction with flipped classroom, wherein } \\
\text { difference were detected regarding the gender variable in favor of } \\
\text { male students }\end{array}$ \\
\hline [19] & $\begin{array}{l}\text { The results showed that the majority of the students were ready and } \\
\text { able to this active learning method }\end{array}$ \\
\hline [20] & Students prefer operating in the flipped mode as it provides them the \\
\hline
\end{tabular}




\begin{tabular}{|l|l|}
\hline & $\begin{array}{l}\text { flexibility to acquire new insights on their own time while getting an } \\
\text { opportunity to interact with peers and teachers during the lecture time }\end{array}$ \\
\hline$[21]$ & $\begin{array}{l}\text { We have found positive signs that a flipped classroom approach can } \\
\text { enhance the student learning experience and outcomes }\end{array}$ \\
\hline$[22]$ & $\begin{array}{l}\text { The outcome of the study revealed that technology integrated learning } \\
\text { environments have positive impacts on students' learning }\end{array}$ \\
\hline
\end{tabular}

Goedhart et al. (2019) indicated, contrary to the drawbacks described, that selfregulated pre-class learning in combination with in-class activities encourages deeper learning. This was confirmed by the research analysis of Awidi and Paynters (2019), who noticed positive signs that a flipped-classroom approach could increase the experience and results of student learning. The most prominent positive outcomes from higher education case studies relating to flipped classrooms confirmed positive results on students' understanding, expertise, and participation (Alamri, 2019; Murillo-Zamorano et al., 2019; Abdekhoda et al., 2020; Bhat et al., 2020). The fact that students adopted active learning in this method is another prominent discovery and is corroborated by research studies (Aljaraideh, 2019; Almisad, 2019; Cilliers \& Pylman, 2020). Also, the chance to develop new perspectives in their own time and the provision of the opportunity to interact with peers and teachers were discussed as beneficial factors during the lecture period (Bhat et al., 2020). This main observation underlines the basic idea behind Constructivism's pedagogical ideology, in which knowledge is built in a passive role through peer interaction rather than by lecturing to the student. Cilliers and Pylman (2020) suggested that another positive aspect identified by students was real-life exposure through conversations with peers, as these could be used for problem-solving as they enter the workplace (Table 3).

\section{Conclusion}

To conclude, among various learning cultures, the flipped classroom design and its implementation were identified as challenges that led to negative experiences of the flipped classroom pedagogy. Furthermore, the review identified that case studies that attested a positive sentiment towards the flipped classroom stated a common perception regarding the merits. Amongst the most commonly noted characteristics were improved student engagement, better academic success, and higher learning outcomes. The review contributed an outline of possible focus areas for future research. Educators would benefit from a practical guide about the best practices in designing their flipped classroom. More importantly, a qualitative inquiry to identify why the flipped classroom was successful in some cultures but failed in others would generate additional scientific value. This could be further strengthened by a meta-analysis that aims to identify a correlation between learning cultures and the perception of flipped classrooms. The purpose of the study was not to generate a versatile stakeholder perspective, but instead to identify areas of improvement through an analysis of perceptions from students in higher education. The paper validated that the majority of the samples have a positive perception towards this learning pedagogy. However, there remain concerns about increased student workload, the ambiguity of expected learning outcomes, and an initial barrier to actively contributing these were identified as the primary implications of the review. 


\section{Acknowledgements}

The author declares having no potential conflicts of interest concerning the research, authorship, and/or publication of this article.

\section{Notes}

${ }^{1}$ Authors' ORCID: https://orcid.org/0000-0003-3253-5133.

2TITLE-ABS-KEY is referring to the syntax Title-Abstract-Keyword.

${ }^{3}$ Origin Country refers to the geographical location from where the sample was collected.

${ }^{4} \mathrm{Mr}$. Kevin Fuchs is currently a lecturer in the Faculty of Hospitality and Tourism, Prince of Songkla University, in Phuket, Thailand. He graduated with a Master of Science in Informatics from Linnaeus University in Sweden and has a keen research interest in topics that revolve around Technology-enhanced Learning (TeL), Connectivism, Contemporary Educational Theories, and the Technology-Enhanced Flipped Classroom (TEFL).

\section{References}

Abdekhoda, M., Maserat, E., \& Ranjbaran, F. (2020). A conceptual model of flipped classroom adoption in medical higher education. Interactive Technology and Smart Education, 17(4), 393-401. doi:10.1108/ITSE-09-2019-0058

Alamri, M. M. (2019). Students' academic achievement performance and satisfaction in a flipped classroom in Saudi Arabia. International Journal of Technology Enhanced Learning, 11(1), 103-119. doi:10.1504/IJTEL.2019.096786

Alebrahim, F., \& Ku, H. Y. (2020). Perceptions of student engagement in the flipped classroom: a case study. Educational Media International, 57(2), 128-147. doi:10.1080/09523987.2020.1786776

Aljaraideh, Y. (2019). Students' perception of flipped classroom: A case study for private universities in Jordan. JOTSE: Journal of Technology and Science Education, 9(3), 368-377. doi:10.3926/jotse.648

Almisad, B. (2019). Perceptions of the'flipped classroom': a case study from a developing country. International Journal of Learning Technology, 14(1), 78-98. doi:10.1504/IJLT.2019.100617

Al-Natour, S., \& Turetken, O. (2020). A comparative assessment of sentiment analysis and star ratings for consumer reviews. International Journal of Information Management, 54, 102132. doi:10.1016/j.ijinfomgt.2020.102132

Aprianto, E., \& Purwati, O. (2020). Multimedia-Assisted Learning in a Flipped Classroom: A Case Study of Autonomous Learning on EFL University Students. International Journal of Emerging Technologies in Learning (IJET), 15(24), 114-127. doi:10.3991/ijet.v15i24.14017

Awidi, I. T., \& Paynter, M. (2019). The impact of a flipped classroom approach on student learning experience. Computers $\mathcal{E}$ Education, 128, 269-283. doi:10.1016/j.compedu.2018.09.013

Bicen, H., \& Beheshti, M. (2019). Assessing perceptions and evaluating achievements of ESL students with the usage of infographics in a flipped classroom learning environment. Interactive Learning Environments, 1-29. doi:10.1080/10494820.2019.1666285

Bhat, S., Raju, R., Bhat, S., \& D'Souza, R. (2020). Redefining quality in engineering education through the flipped classroom model. Procedia Computer Science, 172, 906-914. doi:10.1016/j.procs.2020.05.131 
Cai, J., Yang, H. H., Gong, D., MacLeod, J., \& Zhu, S. (2019). Understanding the continued use of flipped classroom instruction: a personal beliefs model in Chinese higher education. Journal of Computing in Higher Education, 31(1), 137155. doi:10.1007/s12528-018-9196-y

Castedo, R., López, L. M., Chiquito, M., Navarro, J., Cabrera, J. D., \& Ortega, M. F. (2019). Flipped classroom-comparative case study in engineering higher education. Computer Applications in Engineering Education, 27(1), 206-216. doi:10.1002/cae.22069

Cilliers, L., \& Pylman, J. (2020). South African students' perceptions of the flipped classroom: A case study of higher education. Innovations in Education and Teaching International, 1-10. doi:10.1080/14703297.2020.1853588

Colomo-Magaña, E., Soto-Varela, R., Ruiz-Palmero, J., \& Gómez-García, M. (2020). University students' perception of the usefulness of the flipped classroom methodology. Education Sciences, 10(10), 275. doi:10.3390/educsci10100275

Crews, T., \& Butterfield, J. (2014). Data for Flipped Classroom Design: Using Student Feedback to Identify the Best Components from Online and Face-to-Face Classes. Higher Education Studies, 4(3), 38-47. doi:10.5539/hes.v4n3p38

Fuchs, K. (2021). Evaluating The Technology-Enhanced Flipped Classroom Through The Students' Eye: A Case Study. Proceedings of The 3rd International Conference on Research in Education, 2021, Vol. 1, 25-33. doi:10.6084/m9.figshare.14173622

Goedhart, N. S., Blignaut-van Westrhenen, N., Moser, C., \& Zweekhorst, M. B. M. (2019). The flipped classroom: supporting a diverse group of students in their learning. Learning Environments Research, 22(2), 297-310. doi:10.1007/s10984-019-09281-2

Ha, A. S., O'Reilly, J., Ng, J. Y., Zhang, J. H., \& Serpa, S. (2019). Evaluating the flipped classroom approach in Asian higher education: Perspectives from students and teachers. Cogent Education, 6(1), 1638147. doi:10.1080/2331186X.2019.1638147

Kay, R., MacDonald, T., \& DiGiuseppe, M. (2019). A comparison of lecture-based, active, and flipped classroom teaching approaches in higher education. Journal of Computing in Higher Education, 31(3), 449-471. doi:10.1007/s12528-018-9197-x

Liberati, A., Altman, D. G., Tetzlaff, J., Mulrow, C., Gøtzsche, P. C., Ioannidis, J. P., \& Moher, D. (2009). The PRISMA statement for reporting systematic reviews and meta-analyses of studies that evaluate health care interventions: explanation and elaboration. Journal of clinical epidemiology, 62(10), e1-e34. doi:10.1016/j.jclinepi.2009.06.006

Lo, C. K., Lie, C. W., \& Hew, K. F. (2018). Applying "First Principles of Instruction" as a design theory of the flipped classroom: Findings from a collective study of four secondary school subjects. Computers $\mathcal{E}$ Education, 118, 150-165. doi:10.1016/j.compedu.2017.12.003

Lopes, S. F. S. F., Gouveia, L. M. B., \& da Cunha Reis, P. A. (2019). The Flipped Classroom and Higher Education-Experiences with Computer Science Students. International Journal of Advanced Engineering Research and Science, 6(10). doi:10.22161/ijaers.610.3

Martínez-Jiménez, R., \& Ruiz-Jiménez, M. C. (2020). Improving students' satisfaction and learning performance using flipped classroom. The International Journal of Management Education, 18(3), 100422. doi:10.1016/j.ijme.2020.100422

Murillo-Zamorano, L. R., Sánchez, J. Á. L., \& Godoy-Caballero, A. L. (2019). How the flipped classroom affects knowledge, skills, and engagement in higher education: Effects on students' satisfaction. Computers \& Education, 141, 103608. doi:10.1016/j.compedu.2019.103608 
Qiu, J., Liu, C., Li, Y., \& Lin, Z. (2018). Leveraging sentiment analysis at the aspects level to predict ratings of reviews. Information Sciences, 451, 295-309. doi:10.1016/j.ins.2018.04.009

Stovold, E., Beecher, D., Foxlee, R., \& Noel-Storr, A. (2014). Study flow diagrams in Cochrane systematic review updates: an adapted PRISMA flow diagram. Systematic reviews, 3(1), 1-5. doi:10.1186/2046-4053-3-54

Stöhr, C., Demazière, C., \& Adawi, T. (2020). The polarizing effect of the online flipped classroom. Computers $\mathcal{E}$ Education, 147, 103789. doi:10.1016/j.compedu.2019.103789

Tang, T., Abuhmaid, A. M., Olaimat, M., Oudat, D. M., Aldhaeebi, M., \& Bamanger, E. (2020). Efficiency of flipped classroom with online-based teaching under COVID-19. Interactive Learning Environments, 1-12. doi:10.1080/10494820.2020.1817761

Thai, N. T. T., De Wever, B., \& Valcke, M. (2017). The impact of a flipped classroom design on learning performance in higher education: Looking for the best "blend" of lectures and guiding questions with feedback. Computers $\mathcal{E}$ Education, 107, 113-126. doi:10.1016/j.compedu.2017.01.003

Tomas, L., Doyle, T. and Skamp, K., 2019. Are first year students ready for a flipped classroom? A case for a flipped learning continuum. International Journal of Educational Technology in Higher Education, 16(1), p.5. doi:10.1186/s41239-0190135-4

Wilson, K. (2020). What does it mean to do teaching? A qualitative study of resistance to Flipped Learning in a higher education context. Teaching in Higher Education, 114. doi:10.1080/13562517.2020.1822312

\section{Appendix 1}

Table 4: Summary of empirical key findings with sentiment rating

\begin{tabular}{|c|c|c|c|c|c|}
\hline No. & $\begin{array}{l}\text { Author/s } \\
\text { (Year) }\end{array}$ & $\begin{array}{l}\text { Type of Inquiry } \\
\text { (Sample Size) }\end{array}$ & Empirical Findings & Sentiment & Country \\
\hline [01] & $\begin{array}{l}\text { Murillo- } \\
\text { Zamorano et } \\
\text { al. (2019) }\end{array}$ & $\begin{array}{l}\text { Quantitative } \\
\text { Method } \\
(n=160)\end{array}$ & $\begin{array}{l}\text { FC has positive effects on } \\
\text { students' knowledge, } \\
\text { skills, and engagement. }\end{array}$ & Positive & Spain \\
\hline$[02]$ & $\begin{array}{l}\text { Castedo et al. } \\
\text { (2019) }\end{array}$ & $\begin{array}{l}\text { Mixed Methods } \\
(\mathrm{n}=152)\end{array}$ & $\begin{array}{l}\text { Initial reluctance towards } \\
\text { the FC methodology, but } \\
\text { finally a higher attendance } \\
\text { than traditional learning }\end{array}$ & $\begin{array}{l}\text { Slightly } \\
\text { Positive }\end{array}$ & Spain \\
\hline [03] & $\begin{array}{l}\text { Kay et al. } \\
(2019)\end{array}$ & $\begin{array}{l}\text { Quantitative } \\
\text { Method } \\
(n=103)\end{array}$ & $\begin{array}{l}\text { Identified a need for } \\
\text { clarity, flexibility, timely } \\
\text { guidance and feedback, } \\
\text { and cognitive engagement }\end{array}$ & Neutral & Canada \\
\hline [04] & $\begin{array}{l}\text { Lopes et al. } \\
(2019)\end{array}$ & $\begin{array}{l}\text { Quantitative } \\
\text { Method } \\
(\mathrm{n}=152)\end{array}$ & $\begin{array}{l}\text { FC requires a high level of } \\
\text { teacher work and } \\
\text { creativity in developing } \\
\text { content and then properly } \\
\text { organizing it }\end{array}$ & Positive & Portugal \\
\hline [05] & $\begin{array}{l}\text { Goedhart et } \\
\text { al.(2019) }\end{array}$ & $\begin{array}{l}\text { Mixed Methods } \\
(\mathrm{n}=42)\end{array}$ & $\begin{array}{l}\text { The combination of self- } \\
\text { regulated pre-class } \\
\text { learning in combination } \\
\text { with in-class activities } \\
\text { facilitates deeper learning }\end{array}$ & $\begin{array}{l}\text { Slightly } \\
\text { Positive }\end{array}$ & $\begin{array}{l}\text { The } \\
\text { Netherlan } \\
\text { ds }\end{array}$ \\
\hline [06] & Cai et al. & Quantitative & $\begin{array}{l}\text { The migration of materials } \\
\text { from traditional face-to- }\end{array}$ & Neutral & China \\
\hline
\end{tabular}




\begin{tabular}{|c|c|c|c|c|c|}
\hline & (2019) & $\begin{array}{l}\text { Method } \\
(\mathrm{n}=111)\end{array}$ & $\begin{array}{l}\text { face format to computer- } \\
\text { mediated format is a } \\
\text { process that requires } \\
\text { specific skills, as well as a } \\
\text { significant amount of time } \\
\text { and effort }\end{array}$ & & \\
\hline [07] & $\begin{array}{l}\text { Tomas et al. } \\
\text { (2019) }\end{array}$ & $\begin{array}{l}\text { Mixed Methods } \\
(\mathrm{n}=171)\end{array}$ & $\begin{array}{l}\text { Respondents' opinions } \\
\text { regarding whether a } \\
\text { flipped classroom } \\
\text { motivated them to learn, } \\
\text { or was more engaging } \\
\text { than traditional } \\
\text { instruction, were divided }\end{array}$ & Neutral & Australia \\
\hline [08] & Ha et al. (2019) & $\begin{array}{l}\text { Qualitative Method } \\
(\mathrm{n}=13)\end{array}$ & $\begin{array}{l}\text { Students that were used to } \\
\text { a "spoon-fed" approach } \\
\text { initially struggled to adapt } \\
\text { to the flipped classroom } \\
\text { model }\end{array}$ & $\begin{array}{l}\text { Slightly } \\
\text { negative }\end{array}$ & $\begin{array}{l}\text { Hong } \\
\text { Kong }\end{array}$ \\
\hline [09] & $\begin{array}{l}\text { Cilliers \& } \\
\text { Pylman (2020) }\end{array}$ & $\begin{array}{l}\text { Quantitative } \\
\text { Method } \\
(n=82)\end{array}$ & $\begin{array}{l}\text { The activities done in the } \\
\text { classroom provided real- } \\
\text { life experience that could } \\
\text { be used for problem- } \\
\text { solving when they enter } \\
\text { the workplace }\end{array}$ & Positive & $\begin{array}{l}\text { South } \\
\text { Africa }\end{array}$ \\
\hline [10] & $\begin{array}{l}\text { Stöhr et al. } \\
\text { (2020) }\end{array}$ & $\begin{array}{l}\text { Quantitative } \\
\text { Method } \\
(n=52)\end{array}$ & $\begin{array}{l}\text { Results do not confirm the } \\
\text { documented positive } \\
\text { effect of the flipped } \\
\text { classroom in STEM } \\
\text { education }\end{array}$ & Negative & Sweden \\
\hline [11] & $\begin{array}{l}\text { Martínez- } \\
\text { Jiménez \& } \\
\text { Ruiz-Jiménez } \\
\text { (2020) }\end{array}$ & $\begin{array}{l}\text { Quantitative } \\
\text { Method } \\
(n=58)\end{array}$ & $\begin{array}{l}\text { The academic results have } \\
\text { been better in which the } \\
\text { flipped learning } \\
\text { methodology was } \\
\text { implemented }\end{array}$ & Positive & Spain \\
\hline [12] & $\begin{array}{l}\text { Abdekhoda et } \\
\text { al. (2020) }\end{array}$ & $\begin{array}{l}\text { Quantitative } \\
\text { Method } \\
(n=110)\end{array}$ & $\begin{array}{l}\text { An approach that } \\
\text { encourages active learning } \\
\text { and improves student } \\
\text { performance; meanwhile } \\
\text { decreasing the failure rate } \\
\text { in education }\end{array}$ & Positive & Iran \\
\hline [13] & $\begin{array}{l}\text { Colomo- } \\
\text { Magaña et al. } \\
\text { (2020) }\end{array}$ & $\begin{array}{l}\text { Quantitative } \\
\text { Method } \\
(n=123)\end{array}$ & $\begin{array}{l}\text { Sample responded } \\
\text { positively to the initiative } \\
\text { to implement the flipped } \\
\text { classroom and appreciated } \\
\text { its potential to promote } \\
\text { learning }\end{array}$ & Positive & Spain \\
\hline [14] & Alamri (2019) & $\begin{array}{l}\text { Mixed Methods } \\
(\mathrm{n}=52)\end{array}$ & $\begin{array}{l}\text { Results demonstrated } \\
\text { improved student } \\
\text { academic achievement } \\
\text { and satisfaction, compared } \\
\text { with the traditional } \\
\text { lecture-based approach }\end{array}$ & Positive & $\begin{array}{l}\text { Saudi } \\
\text { Arabia }\end{array}$ \\
\hline [15] & Wilson (2020) & $\begin{array}{l}\text { Qualitative Method } \\
(\mathrm{n}=25)\end{array}$ & $\begin{array}{l}\text { This study highlights } \\
\text { important problems } \\
\text { associated with Flipped } \\
\text { Learning pedagogy and } \\
\text { suggests future research in } \\
\text { divergent pedagogies } \\
\text { attend to the critical issues } \\
\text { of student workload, and } \\
\text { to consider if the same }\end{array}$ & Negative & Australia \\
\hline
\end{tabular}




\begin{tabular}{|c|c|c|c|c|c|}
\hline & & & $\begin{array}{l}\text { educational outcome } \\
\text { could be achieved equally } \\
\text { as well by a lower } \\
\text { workload pedagogy. }\end{array}$ & & \\
\hline [16] & $\begin{array}{l}\text { Alebrahim \& } \\
\text { Ku (2020) }\end{array}$ & $\begin{array}{l}\text { Qualitative Method } \\
(\mathrm{n}=14)\end{array}$ & $\begin{array}{l}\text { Positive and negative } \\
\text { opinions depending on } \\
\text { how they implemented } \\
\text { the flipped classroom } \\
\text { including the engagement } \\
\text { of students and the } \\
\text { environment }\end{array}$ & Neutral & $\begin{array}{l}\text { United } \\
\text { States }\end{array}$ \\
\hline [17] & $\begin{array}{l}\text { Aprianto \& } \\
\text { Purwati (2020) }\end{array}$ & $\begin{array}{l}\text { Qualitative Method } \\
(\mathrm{n}=15)\end{array}$ & $\begin{array}{l}\text { The use of efficient } \\
\text { technology must be } \\
\text { reviewed prior to use } \\
\text { because it helps facilitate } \\
\text { outside-class engagement } \\
\text { amongst students }\end{array}$ & $\begin{array}{l}\text { Slightly } \\
\text { Positive }\end{array}$ & Indonesia \\
\hline [18] & $\begin{array}{l}\text { Aljaraideh } \\
(2019)\end{array}$ & $\begin{array}{l}\text { Quantitative } \\
\text { Method } \\
(n=495)\end{array}$ & $\begin{array}{l}\text { Generally a high } \\
\text { satisfaction with flipped } \\
\text { classroom, wherein } \\
\text { difference were detected } \\
\text { regarding the gender } \\
\text { variable in favor of male } \\
\text { students }\end{array}$ & Positive & Jordan \\
\hline [19] & $\begin{array}{l}\text { Almisad } \\
\text { (2019) }\end{array}$ & $\begin{array}{l}\text { Mixed Methods } \\
(\mathrm{n}=27)\end{array}$ & $\begin{array}{l}\text { The results showed that } \\
\text { the majority of the } \\
\text { students were ready and } \\
\text { able to this active learning } \\
\text { method }\end{array}$ & Positive & Kuwait \\
\hline [20] & $\begin{array}{l}\text { Bhat et al. } \\
(2020)\end{array}$ & $\begin{array}{l}\text { Mixed Methods } \\
(\mathrm{n}=32)\end{array}$ & $\begin{array}{l}\text { Students prefer operating } \\
\text { in the flipped mode as it } \\
\text { provides them the } \\
\text { flexibility to acquire new } \\
\text { insights on their own time } \\
\text { while getting an } \\
\text { opportunity to interact } \\
\text { with peers and teachers } \\
\text { during the lecture time }\end{array}$ & Positive & India \\
\hline [21] & $\begin{array}{l}\text { Awidi \& } \\
\text { Paynter (2019) }\end{array}$ & $\begin{array}{l}\text { Mixed Methods } \\
(\mathrm{n}=117)\end{array}$ & $\begin{array}{l}\text { We have found positive } \\
\text { signs that a flipped } \\
\text { classroom approach can } \\
\text { enhance the student } \\
\text { learning experience and } \\
\text { outcomes }\end{array}$ & $\begin{array}{l}\text { Slightly } \\
\text { Positive }\end{array}$ & Australia \\
\hline [22] & $\begin{array}{l}\text { Bicen \& } \\
\text { Beheshti } \\
\text { (2019) }\end{array}$ & $\begin{array}{l}\text { Mixed Methods } \\
(\mathrm{n}=130)\end{array}$ & $\begin{array}{l}\text { The outcome of the study } \\
\text { revealed that technology } \\
\text { integrated learning } \\
\text { environments have } \\
\text { positive impacts on } \\
\text { students' learning }\end{array}$ & Positive & Cyprus \\
\hline
\end{tabular}

